Article

\title{
Immobilization of glucose oxidase in liposome-templated biomimetic silica particles
}

\author{
ZHU Yanan a, JIANG Yanjun a,b,*, GAO Jing a,\#, ZHOU Liya a , HE Ying a, JIA Fei a \\ a Institute of Chemical Technology, Hebei University of Technology, Tianjin 300130, China \\ b State Key Laboratory of Biology Engineering, Institute of Process Engineering, Chinese Academy of Sciences, Beijing 100190, China
}

\section{A R T I C L E I N F O}

Article history:

Received 30 October 2012

Accepted 24 December 2012

Published 20 April 2013

\section{Keywords:}

Biomimetic silicification

Liposome

Glucose oxidase

Immobilized enzyme

\begin{abstract}
A B S T R A C T
Glucose oxidase (GOx) was immobilized in biomimetic silica particles by coupling liposome vesicles with a biomimetic silicification process simulating a cell microenvironment. SEM images showed that the immobilized GOx particles were spherical, and their diameter was approximately $200 \mathrm{~nm}$. The recovery of GOx reached $71.8 \%$ under the optimized reaction conditions. The immobilized GOx showed improved thermal and $\mathrm{pH}$ stability, and its tolerance to denaturants and reusability were also greatly improved. This was attributed to the space limitations and stable environment in the support.
\end{abstract}

(c) 2013, Dalian Institute of Chemical Physics, Chinese Academy of Sciences. Published by Elsevier B.V. All rights reserved.

sembly of inorganic particles, and thus satisfactory particles cannot be obtained [12]. In addition, the sol-gel process must be conducted under extremely high or low $\mathrm{pH}$. Thus, the wide application of the sol-gel process has been limited for enzyme immobilization. Biomimetic silicification is a mild and controllable process that simulates the silicification process in organisms; it has attracted much attention from researchers $[13,14]$. Morse et al. [15] immobilized firefly luciferase with cysteamine, as an inducer. They achieved this by simulating the hydrolysis and polymerization of tetramethoxysilane (TMOS) catalyzed by silicatein [16]. To avoid the disadvantages of the sol-gel process, Galarneau et al. [17-20] adopted a one-pot method to immobilize lipase and horse radish peroxidase. In their experiments, lecithin and lauryl amine, which acted as inducers, were added to ethanol, and an enzyme-containing solution was

\footnotetext{
*Corresponding author. Tel/Fax: +86-22-60204945; E-mail: yanjunjiang@hebut.edu.cn

\# Corresponding author. Tel/Fax: +86-22-60204293; E-mail: jgao@hebut.edu.cn

This work was supported by the National Nature Science Foundation of China $(21006020,21276060,21276062)$, the Natural Science Foundation of Hebei Province (B2010000035, B2011202095), the Science and Technology Research Key Project of Higher School in Hebei Province (ZD2010118) and the Application Basic Research Plan Key Basic Research Project of Hebei Province (11965150D), and the Open Funding Project of the National Key Laboratory of Biochemical Engineering (China).

DOI: 10.1016/S1872-2067(11)60519-6 | http://www.sciencedirect.com/science/journal/18722067 | Chin. J. Catal.,Vol. 34, No. 4, April 2013
} 


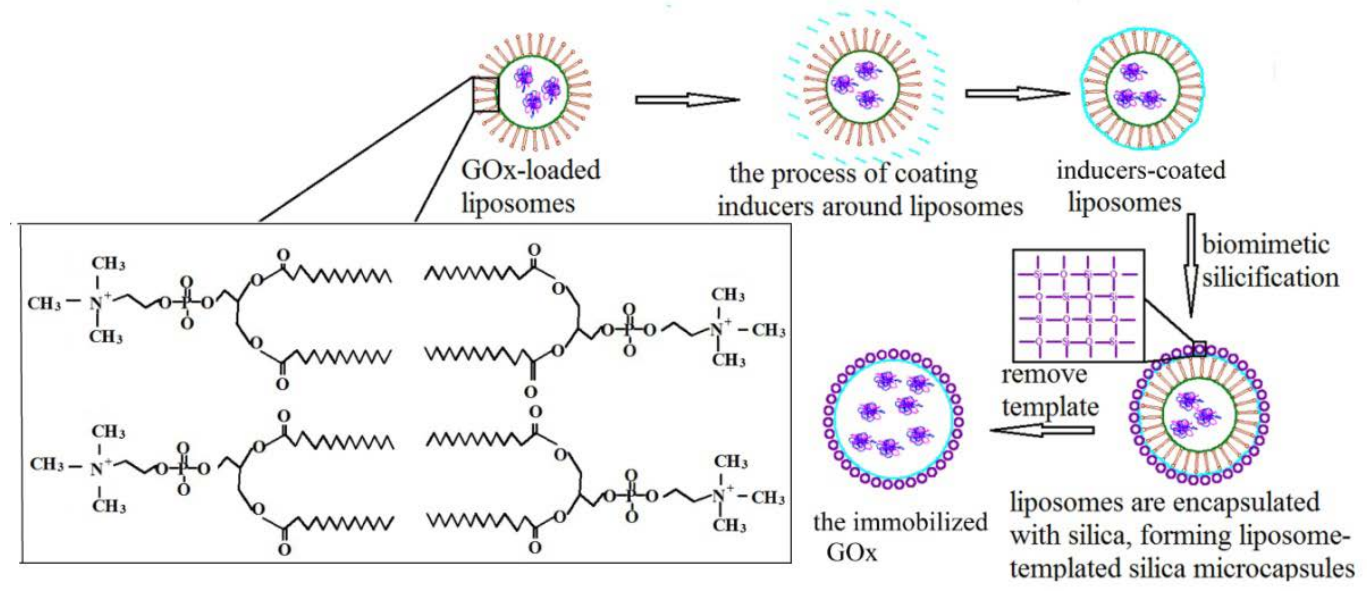

Scheme 1. The process used for the preparation of immobilized glucose oxidase (GOx).

then added. In this procedure, two processes occurred simultaneously; the enzyme-containing liposome microcapsule was prepared, and the lauryl amine-induced biomimetic silicification was completed. This method avoided direct contact between the enzyme and the silica, and modified the carrier morphology under mild conditions. However, this technique must be improved if it is to allow the preparation of controllable carriers.

Based on the foundation of biomimetic silicification, the current work developed a new process for enzyme immobilization. First, an enzyme was packed into the liposome. Second, using the liposome as the template and poly dimethyl diallyl ammonium (PDADMA) as an inducer, the silicon precursor was dehydrated to form a silica shell on the surface of liposome. Finally, the template was removed using Triton X-100. This process realized the separation of the enzyme and the intricate embedding environment, and avoided covalent interactions between the enzyme and silanol. Thus, high enzyme activity was retained. The morphology of the silica particles could also be controlled, using the liposome as the template in the process, and the removal of the template improved the mass transfer in the catalytic process.

\section{Experimental}

\subsection{Preparation of the glucose oxidase (GOx)-loaded liposome template}

Lecithin (Aoboxing Biological Technology Limited, Beijing) and cholesterol (Aoboxing Biological Technology Limited, Beijing) were solved at a mass ratio of 4:1 into chloroform (Jiangtian Chemical Technology Limited, Tianjin), resulting in a phospholipid stock solution that was stored at $4{ }^{\circ} \mathrm{C}$ before use. The phospholipid solution (100 ml) was added to a flask, and the chloroform was evaporated using a vacuum rotary evaporator, leaving a thin lipid film. Some GOx solution (100 mmol/L PBS, pH 7) was added to the flask, and the mixture was then sonicated to form the GOx-loaded liposome template.

\subsection{Preparation of GOx-loaded silica}

PDADMA solution (2 mg/ml, $100 \mathrm{mmol} / \mathrm{L} \mathrm{PBS,} \mathrm{pH} \mathrm{7)} \mathrm{and}$ TMOS hydrolyzate $(8.188 \mathrm{mg} / \mathrm{ml}, \mathrm{pH} 7)$ were added to the GOx-loaded liposome template solution under intense agitation, to form GOx-loaded silica templating liposomes. Solidification of the hydrogel occurred within $60 \mathrm{~min}$. Immediately after the GOx-loaded silica particles were formed, the excess PDADMA and GOx were removed, using five cycles of centrifugation and washing with distilled water.

\subsection{Template removal}

The GOx-loaded silica particles were soaked in a Trinton $\mathrm{X}-100$ solution for $60 \mathrm{~min}$ to remove the template, using two cycles of centrifugation and washing with distilled water. In this way, the immobilized GOx was obtained. The process is presented in Scheme 1.

\subsection{Entrapping efficiency of $G O x$}

The protein content in the supernatant solution was tested using the Coomassie brilliant blue G-250-binding method. The entrapping rate $E(\%)$ was calculated using the following the equation

$$
E=100 \% \times\left(1-P_{\mathrm{s}} / P_{\mathrm{t}}\right)
$$

where $P_{\mathrm{s}}$ and $P_{\mathrm{t}}$ are the protein content (mg) in the supernatant solution and the total initial added protein content (mg), respectively.

\subsection{Assays for enzyme activity}

A bienzymatic system was designed to assay the GOx activity. The $\mathrm{H}_{2} \mathrm{O}_{2}$ generated in-situ by the reaction of glucose with air using GOx reacted with phenol and 4-aminoantipyridine (4-AAP), catalyzed by horseradish peroxidase (HRP). The colored product formed during the reaction was detected using UV spectroscopy at $500 \mathrm{~nm}$, and the activity of the enzyme was then calculated.

Definition of the activity: One unit of activity $(U)$ was defined as the enzyme mass that resulted in the production of 1 $\mu \mathrm{mol}$ of $\mathrm{H}_{2} \mathrm{O}_{2}$ per minute at $40^{\circ} \mathrm{C}$ and $\mathrm{pH} 6$. 
(1) Assay of $\mathrm{H}_{2} \mathrm{O}_{2}$ standard equation.

(2) Preparation of the substrate solution. Solution A contained $0.35 \mathrm{mg}$ of HRP, $0.35 \mathrm{mg}$ of 4 -AAP, $1 \mathrm{ml}$ of phenol $(3 \%$ mass ratio), and $20 \mathrm{ml}$ of PBS $(0.1 \mathrm{mmol} / \mathrm{ml})$. Solution B was a glucose solution (with a $13 \%$ mass ratio).

(3) Operating process. A standard assay solution was prepared by thoroughly mixing $1.5 \mathrm{ml}$ of Solution A and $1.5 \mathrm{ml}$ of Solution B; the reaction was initiated by the addition of Solution B to Solution A and the immobilized GOx mixture, and the sample was then shaken for $1 \mathrm{~min}$. The absorbance of the supernatant was recorded at $500 \mathrm{~nm}$.

The activity $(U)$ was calculated using the following equation

$$
U=\frac{t \times m}{V\left(C_{\mathrm{o}}-C_{\mathrm{e}}\right) \times 10^{3}}
$$

where $t$ is the reaction time ( $\mathrm{min}), m$ is the mass of immobilized and free GOx (g), $V$ is the volume of reaction liquid (ml), and $C_{0}$ and $C_{\mathrm{e}}$ are the initial and final $\mathrm{H}_{2} \mathrm{O}_{2}$ concentrations (mol/L), respectively.

The activity recovery was calculated using the equation

$$
R e=100 \% \times A_{\mathrm{i}} / A_{f}, A_{\mathrm{f}}=A_{\mathrm{f}^{\prime}} \times E,
$$

where $A_{\mathrm{i}}$ and $A_{\mathrm{f}}$ are the actual activity and theoretical activity of the immobilized GOx $(U)$, respectively, $A_{\mathrm{f}^{\prime}}$ is the total activity of free GOx used in the process $(U)$, and $E$ is the entrapping rate (\%).

\section{Results and discussion}

The effects of PDADMA ( $2 \mathrm{mg} / \mathrm{ml}, 100 \mathrm{mmol} / \mathrm{L}$ PBS, pH 6), TMOS $(8.188 \mathrm{mg} / \mathrm{ml})$, Triton $\mathrm{X}-100$, and the ultrasonication time on the GOx immobilization were investigated. The results showed that the highest activity recovery was obtained with a liposome concentration of $18.75 \mathrm{mg} / \mathrm{ml}$ (dry weight), PDADMA added at $0.02 \mathrm{mg} / \mathrm{mg}$, and TMOS added at $0.262 \mathrm{mg} / \mathrm{mg}$; at a TritonX-100 concentration of $1.5 \%(\mathrm{w} / \mathrm{w})$, the template could be most thoroughly removed, and the surfactant had the smallest effect on the enzyme. In the process of liposome breakup and recombination, sonication contributed to the formation of uniform particles with small diameter and high activity, but it also destroyed the active sites. Considering the balance between these factors, the ultrasonication time was fixed at $120 \mathrm{~min}$.

\subsection{Diameter of the liposomes and the immobilized GOx}

The liposomes were prepared using the film dispersion method. The breakup and recombination were achieved using sonication; the liposome diameter could be controlled by limiting the ultrasonication time. The diameters of the liposomes and the immobilized GOx were analyzed using dynamic light scattering (DLS), and the results are presented in Fig. 1. The liposome diameter decreased and the degree of dispersion increased with time, up to an ultrasonication time of $120 \mathrm{~min}$. For ultrasonication times over $120 \mathrm{~min}$, the liposome diameters remained at approximately $50 \mathrm{~nm}$.

Figure 1 indicated that the liposomes with small diameters contributed to the formation of the immobilized GOx, which also had a small diameter, and was uniformly dispersed. The diameter of the immobilized GOx was approximately $200 \mathrm{~nm}$ when the template produced with an ultrasonication time of $120 \mathrm{~min}$ was used, and approximately $900 \mathrm{~nm}$ when no template was used. This showed that the template effectively controlled the diameter of the immobilized GOx.

\subsection{Effect of ultrasonication time on the activity of the immobilized GOX}

The effect of the ultrasonication time on the activity of the immobilized GOx was investigated and the results are presented in Fig. 2. The activity of the immobilized GOx first increased

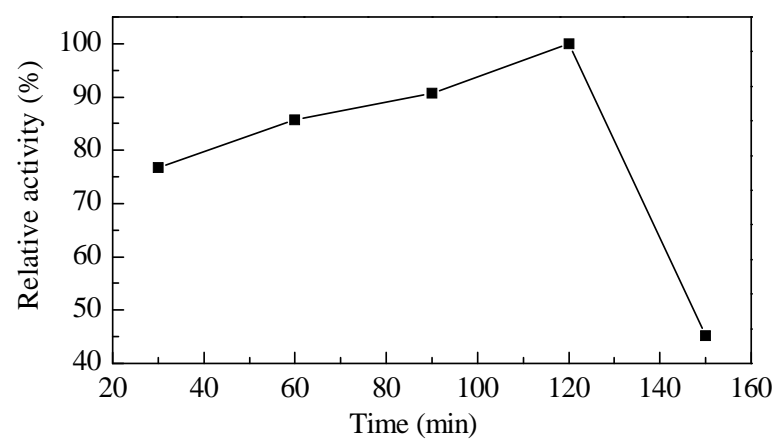

Fig. 2. Influence of ultrasonication time on the relative activity of the immobilized GOx.
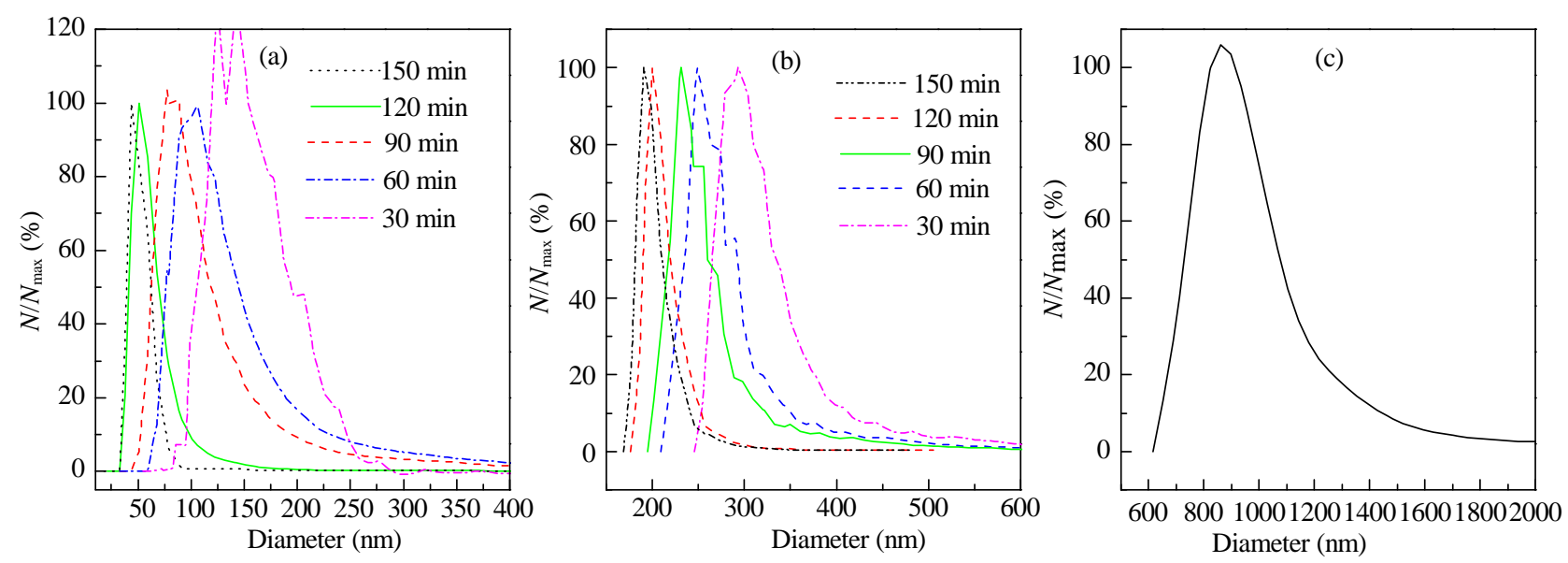

Fig. 1. Diameters of liposomes (a), liposome-templated microcapsules (b), and non-templated microcapsules (c). 


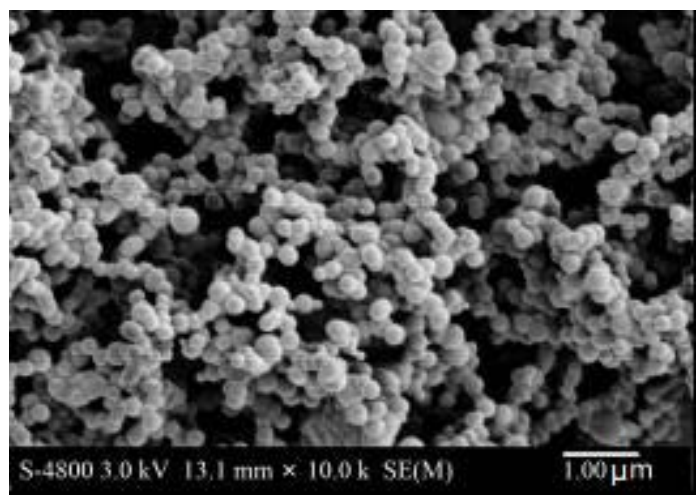

Fig. 3. SEM image of immobilized GOx.

and then decreased with time. Increases in the ultrasonication time decreased the diameter of the immobilized GOx, and this increased the activity. With further increases in the ultrasonication time over $120 \mathrm{~min}$, the diameter of the immobilized GOx showed a slight change, but the ultrasonication destroyed the active sites on the immobilized GOx. Thus, the highest activity was obtained with an ultrasonication time of $120 \mathrm{~min}$.

\subsection{Scanning electron microscopy (SEM) analysis}

The morphology of the immobilized GOx was observed using SEM (S-4800, JEOL). The SEM images (Fig. 3) indicated that the immobilized GOx showed relatively uniform structures, due to the use of the template, and the average diameter was approximately $200 \mathrm{~nm}$. The immobilized GOx showed high activity.

\subsection{Thermal stability of immobilized and free GOX}

The thermal stability of the immobilized and free GOx was evaluated by incubating the enzyme at different temperatures for $120 \mathrm{~min}$, and then measuring the relative activity. The results in Fig. 4 showed that the immobilized GOx lost $60 \%$ of its activity at $70{ }^{\circ} \mathrm{C}$, while the free GOx was completely inactivated. More than $80 \%$ of the activity of the immobilized GOx was maintained when the temperature was lower than $50{ }^{\circ} \mathrm{C}$. This was consistent with previous studies [21], which reported that the thermal stability of immobilized GOx was greatly improved,

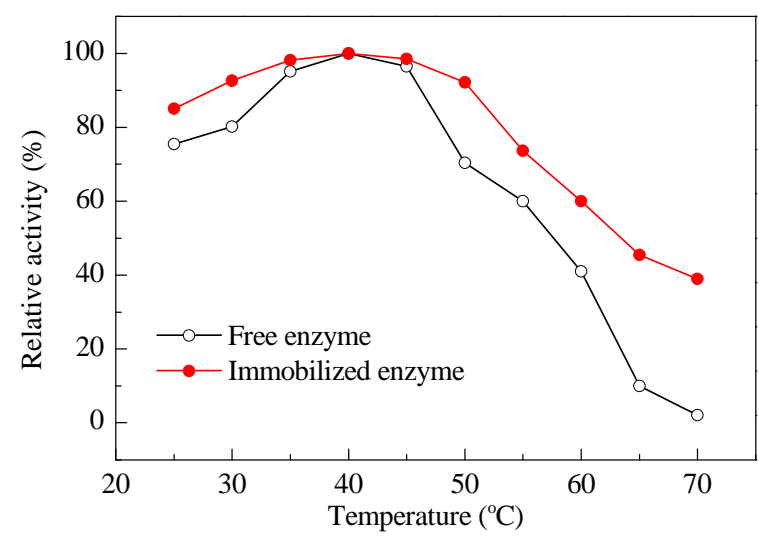

Fig. 4. Thermal stability of immobilized and free GOx.

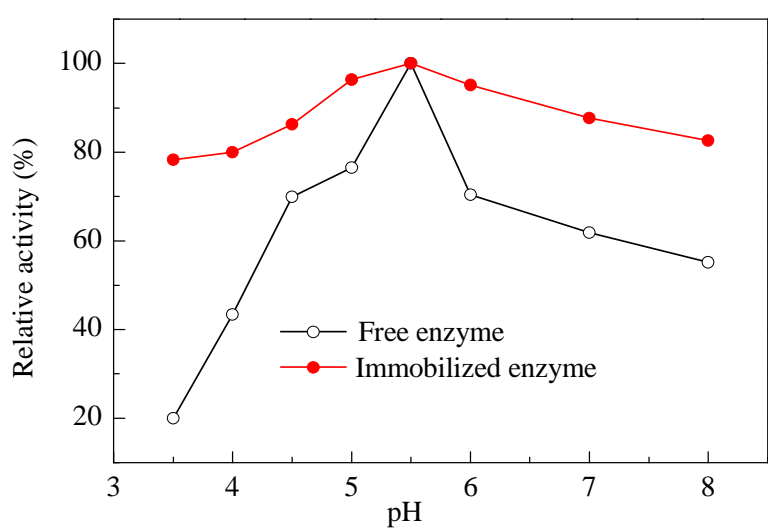

Fig. 5. $\mathrm{pH}$ stability of immobilized and free GOx.

compared with the free enzyme. The reason for this was that the microenvironment provided by the silica effectively limited the dissociation of the hydrated sheath, as well as the conformational changes of the GOx molecule [22].

\section{5. $p H$ stability of immobilized and free GOx}

The stabilities of free and immobilized G0x were compared at different $\mathrm{pH}$ values (3.5 to 8) after they were incubated for 120 min in buffer. From Fig. 5, the immobilized GOx presented higher activity than the free GOx over a wide $\mathrm{pH}$ range. The activity of the free GOx drastically decreased at $\mathrm{pH}$ values lower than 4.5 , while the immobilized GOx retained $78.3 \%$ of its activity. At pH 8.0, the relative activity of the immobilized GOx reached $82.6 \%$, 55.2\% higher than that of the free GOx. These results were consistent with previous reports [21].

In extreme-pH environments, the frequent attacks from $\mathrm{OH}^{-}$ or $\mathrm{H}_{3} \mathrm{O}^{+}$significantly affected the net charge of the enzyme molecules. This weakened the static interactions between the molecules, and then destroyed the hydrated layer of the enzyme molecule. As a result, the enzyme conformation was changed. The presence of silica decreased the frequency of the attacks from $\mathrm{OH}^{-}$or $\mathrm{H}_{3} \mathrm{O}^{+}$, and thus the $\mathrm{pH}$ stability of the enzyme was improved [22].

\subsection{Stability in the presence of denaturing agents}

In general, enzymes react in a complex environment, where a huge mass of intermediate products are produced. These products often have an inhibitory action on the enzymes. To investigate the behavior of GOx in such environments, the stability of immobilized and free GOx against $\mathrm{GuHCl}$, urea, and $\mathrm{H}_{2} \mathrm{O}_{2}$ were investigated.

$\mathrm{GuHCl}$ and urea are widely used denaturants in the study of protein stability. Compared with extreme $\mathrm{pH}$, high temperature, and other denaturants, $\mathrm{GuHCl}$ and urea are more effective in denaturing enzymes. $\mathrm{GuHCl}$ at a low concentration greatly decreased the GOx activity under neutral conditions, but could not change its conformation [22]. The immobilized GOx retained high stability in conformation, even at high $\mathrm{GuHCl}$ or urea concentrations.

$\mathrm{GuHCl}$ is a bi-functional reagent in which the guanidinium 
ion has a strong denaturing effect. The GuHCl-induced denaturation can be attributed to both its denaturant and ionic properties. $\mathrm{GuHCl}$ is more effective than urea in denaturing enzymes. It has been reported that $\mathrm{GuHCl}$ merely destroyed the enzyme ionosphere at concentrations lower than $1.8 \mathrm{~mol} / \mathrm{L}$, but destroyed the secondary structure of enzymes when its concentration was increased to 2-4 mol/L [22]. In the current work, the immobilized and free enzymes were incubated in a 2 $\mathrm{mol} / \mathrm{L} \mathrm{GuHCl}$ solution for $120 \mathrm{~min}$, and their residual activities were then compared. The results shown in Fig. 6(a) indicated that the immobilized enzyme had more activity than the free enzyme. This was attributed to the stable microenvironment and space restrictions provided by the carriers.

A low concentration of urea changed the microenvironment around the active sites, and approximately $90 \%$ of the activity was retained after the complete removal of the urea. The urea greatly decreased the enzyme activity at a concentration of 2 $\mathrm{mol} / \mathrm{L}$, and resulted in irreversible denaturation of the enzyme at $8 \mathrm{~mol} / \mathrm{L} \mathrm{[22].} \mathrm{In} \mathrm{the} \mathrm{experiments,} \mathrm{the} \mathrm{immobilized} \mathrm{and} \mathrm{free}$ GOx were incubated in $8 \mathrm{~mol} / \mathrm{L}$ of urea for $120 \mathrm{~min}$, and their residual activities were then compared. Figure $6(\mathrm{~b})$ shows that the immobilized GOx displayed better stability against urea than the free GOx.

$\mathrm{H}_{2} \mathrm{O}_{2}$, an unavoidable reaction product, accumulates around active sites and results in the inactivation and shorter service life of enzymes [23]. In the experiments, the immobilized and free enzymes were incubated in $10 \mathrm{mmol} / \mathrm{L}$ of $\mathrm{H}_{2} \mathrm{O}_{2}$ for 120 min, and their residual activities were then compared. The results are shown in Fig. 6(c). The immobilized enzymes showed

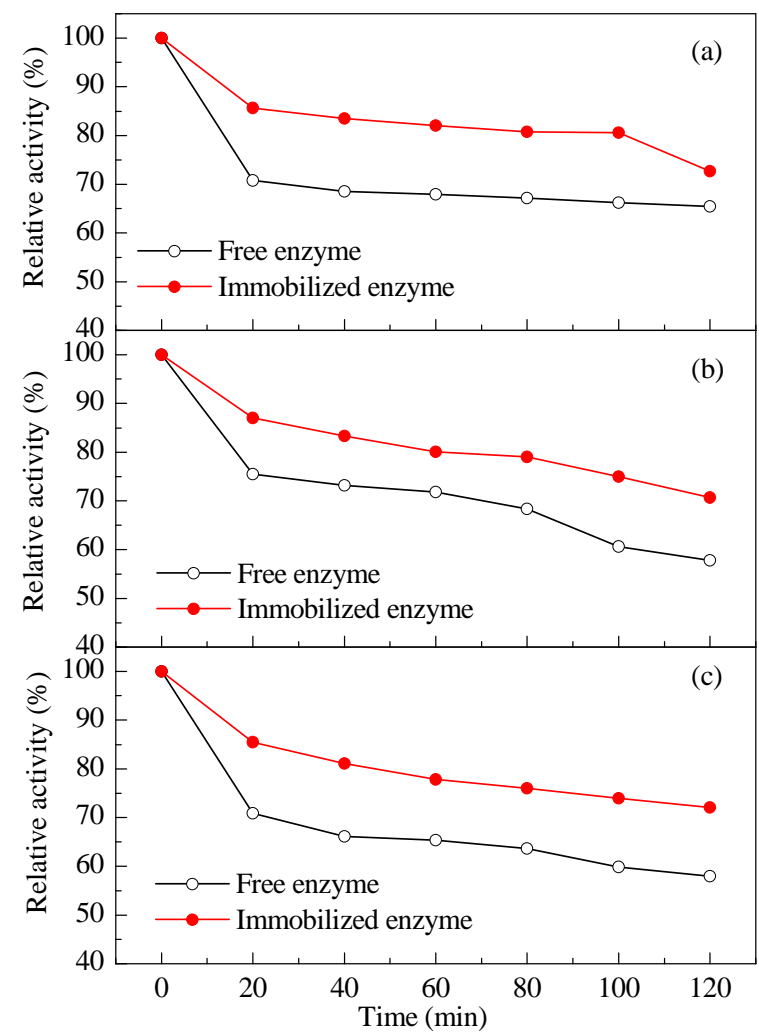

Fig. 6. Influence of different denaturants on the activity of immobilized and free GOx. (a) $2 \mathrm{~mol} / \mathrm{L} \mathrm{GuHCl}$; (b) $8 \mathrm{~mol} / \mathrm{L}$ urea; (c) $10 \mathrm{mmol} / \mathrm{L} \mathrm{H}_{2} \mathrm{O}_{2}$.

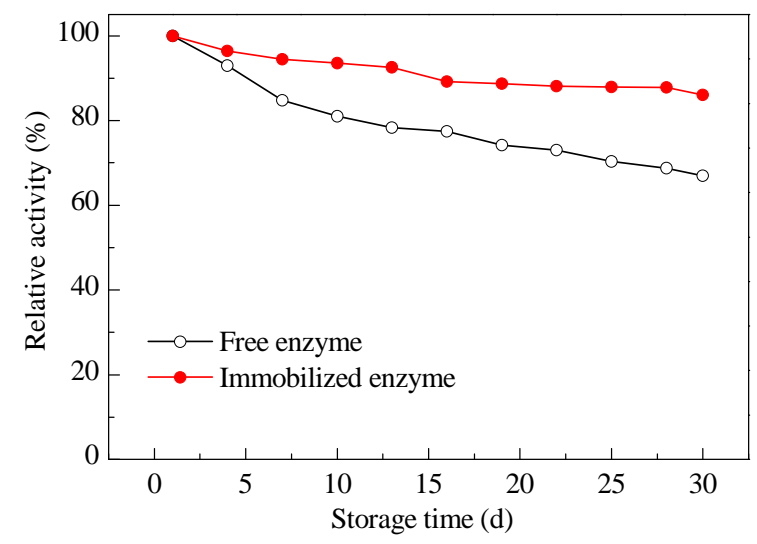

Fig. 7. Storage stability of immobilized and free GOx.

better stability against $\mathrm{H}_{2} \mathrm{O}_{2}$ than the free GOx. The microenvironment of the immobilized enzymes resulted in the enrichment of $\mathrm{H}_{2} \mathrm{O}_{2}$ around the active sites, and simultaneously prevented the dissociation of the active sites. All considered, the $\mathrm{H}_{2} \mathrm{O}_{2}$ enrichment played a smaller role than the space restrictions, so the immobilized enzyme showed better stability against $\mathrm{H}_{2} \mathrm{O}_{2}$ than the free $\mathrm{GOx}$.

\subsection{Storage stability of immobilized and free GOX}

The remaining activity was evaluated after the enzyme was stored in pH 6 buffer at $4{ }^{\circ} \mathrm{C}$ for $30 \mathrm{~d}$. The results given in Fig. 7 show that the remaining activities of the immobilized and free GOx were $86 \%$ and $67 \%$ of the initial activity, respectively. This indicated that the immobilized enzyme had the higher storage stability. The enzyme activity decreased during the storage, because of degradation resulting from the presence of microorganisms. For the immobilized enzyme, the micropores in the carriers effectively prevented the invasion of microorganisms [24]. As a result, the immobilized GOx showed high storage stability.

\subsection{Operational stability of immobilized GOx}

The operational stability of immobilized GOx was investigated. The reaction was repeated for seven batches, and $74 \%$ of the initial activity was retained (Fig. 8). The activity loss after the reaction was attributed to the accumulation of free radicals

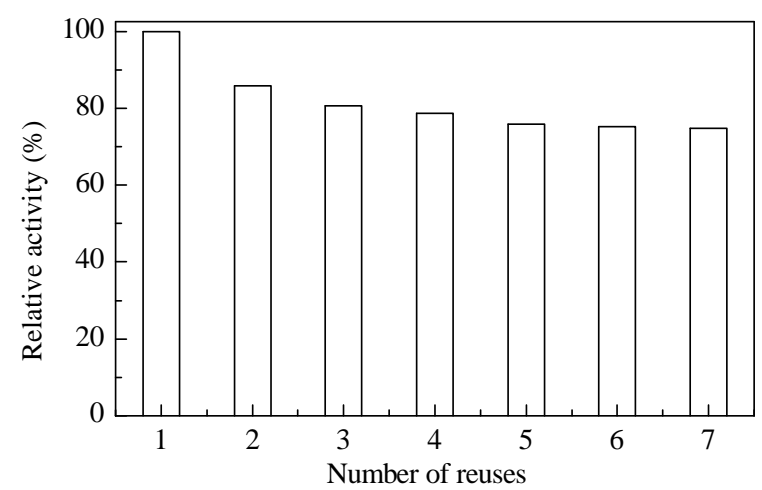

Fig. 8. Operational stability of immobilized GOx. 


\section{Graphical Abstract}

Chin. J. Catal., 2013, 34: 741-750 doi: 10.1016/S1872-2067(11)60519-6

Immobilization of glucose oxidase in liposome-templated biomimetic silica particles

ZHU Yanan, JIANG Yanjun*, GAO Jing*, ZHOU Liya, HE Ying, JIA Fei

Hebei University of Technology; Institute of Process Engineering, Chinese Academy of Sciences

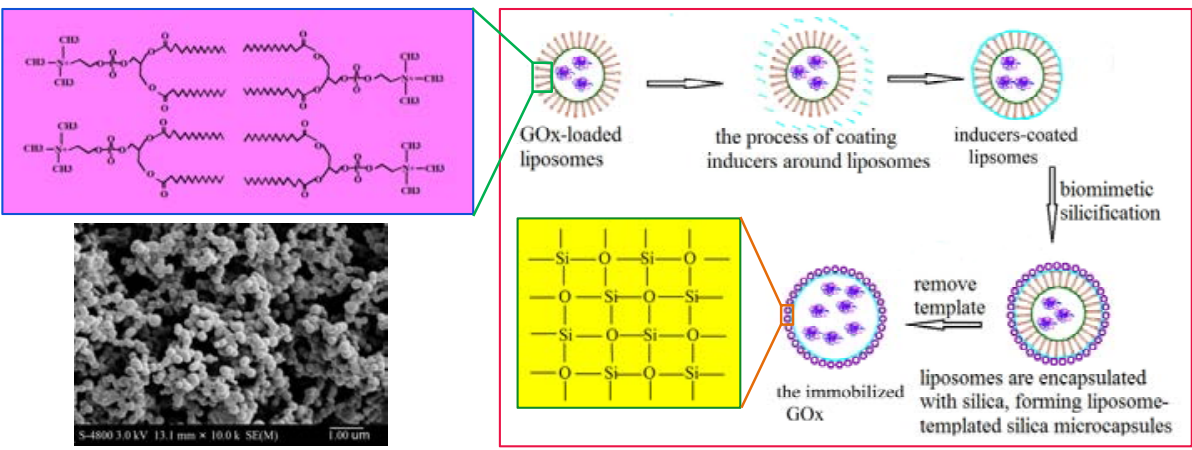

Glucose oxidase (GOx) was immobilized in silica particles through the combination of liposome vesicles with biomimetic silicification process. The thermal, $\mathrm{pH}$, and operational stabilities of the immobilized GOx were significantly improved. This study provides a novel method for preparation of silica-immobilized enzymes.

around the enzymes [22]. In addition, the GOx immobilized with silica allowed the possibility of recovering the biocatalyst from the medium after the reaction.

\section{Conclusions}

In the present work, the integration of liposomes and biomimetic silicification was used to immobilize GOx. This system protected the actives sites and the conformation of GOx during the silicification process. Liposomes were used as the template to control the morphology and diameter of the silica, and served as a coating to protect the enzymes from reactive silane reagents such as hydroxyl and amino groups. Biomimetic silicification took place under mild reaction conditions, compared with the traditional sol-gel process. The removal of the template with surfactant optimized the transfer of the substrate and the product. The thermal and operational stabilities of the immobilized GOx were significantly improved compared with the free GOx. The immobilized GOx was much more resistant to denaturing agents. The immobilization of GOx in liposome-templated biomimetic silica particles could provide new insights into the interactions between proteins and silica.

\section{References}

[1] de Marcos S, Galindo J, Sierra J F, Galban J, Castillo J R. Sens Actuators $B, 1999,57: 227$

[2] Reetz M T, Tielmann P, Wiesenhöfer W, Könen W, Zonta A. Adv Synth Catal, 2003, 345: 717

[3] Keeling-Tucker T, Rakic M, Spong C, Brennan J D. Chem Mater, 2000, 12: 3695

[4] Jin W, Brennan J D. Anal Chim Acta, 2002, 461: 1

[5] Das S, Berke-Schlessel D, Ji H F, McDonough J, Wei Y. J Mol Catal B,
2011, 70: 49

[6] Campbell A, Taylor P, Cayre O J, Paunov V N. Chem Commun, 2004: 2378

[7] Nara T Y, Togashi H, Ono S, Egami M, Sekikawa C, Suzuki Y-h, Masuda I, Ogawa J, Horinouchi N, Shimizu S, Mizukami F, Tsunoda T. J Mol Catal B, 2011, 68: 181

[8] Ambati J, Lopez A M, Cochran D, Wattamwar P, Bean K, Dziubla T D, Rankin S E. Acta Biomater, 2012, 8: 2096

[9] Wang Y J, Caruso F. Chem Mater, 2006, 18: 4089

[10] Begu S, Girod S, Lerner D A, Jardiller N, Tourne-Peteilh C, Devoisselle J M. J Mater Chem, 2004, 14: 1316

[11] Steinberg Y, Schroeder A, Talmon Y, Schmidt J, Khalfin R L, Cohen Y, Devoisselle J M, Begu S, Avnir D. Langmuir, 2007, 23: 12024

[12] Li Y, Yip W T. J Am Chem Soc, 2005, 127: 12756

[13] Natalio F, Link T, Müller W E G, Schröder H C, Cui F Zh, Wang X H, Wiens M. Acta Biomater, 2010, 6: 3720

[14] Müller W E G, Boreiko A, Wang X H, Belikov S I, Wiens M, Grebenjuk V A, Schlossmacher U, Schröder H C. Gene, 2007, 395: 62

[15] Roth K M, Zhou Y, Yang W J, Morse D E. J Am Chem Soc, 2005, 127 : 325

[16] Wiens M, Bausen M, Natalio F, Link T, Schlossmacher U, Müller W E G. Biomaterials, 2009, 30: 1648

[17] Galarneau A, Mureseanu M, Atger S, Renard G, Fajula F. New J Chem, 2006, 30: 562

[18] Galarneau A, Sartori F, Cangiotti M, Mineva T, Di Renzo F, Ottaviani M F. J Phys Chem B, 2010, 114: 2140

[19] Phuoc L T, Laveille P, Chamouleau F, Renard G, Drone J, Coq B, Fajula F, Galarneau A. Dalton Trans, 2010, 39: 8511

[20] Galarneau A, Renard G, Mureseanu M, Tourrette A, Biolley C, Choi M, Ryoo R, Di Renzo F, Fajula F. Microporous Mesoporous Mater, 2007, 104: 103

[21] Li Q W, Luo G A, Wang Y M, Zhang X R. Mater Sci Eng C, 2000, 11: 67

[22] Devaraj K B, Kumar P R, Prakash V. Process Biochem, 2011, 46: 458 
[23] Taboada-Puig R, Junghanns C, Demarche P, Moreira M T, Feijoo G, Lema J M, Agathos S N. Bioresour Technol, 2011, 102: 6593
[24] Luckarift H R, Spain J C, Naik R R, Stone M O. Nat Biotechnol, 2004, 22: 211

\title{
脂质体为模板仿生硅化固定葡萄糖氧化酶 \\ 朱亚男 ${ }^{\mathrm{a}}$, 姜艳军 ${ }^{\mathrm{a}, \mathrm{b},}$, 高 静 ${ }^{\mathrm{a}, \#}$, 周丽亚 ${ }^{\mathrm{a}}$, 贺 莹 ${ }^{\mathrm{a}}$, 贾 霏 $^{\mathrm{a}}$

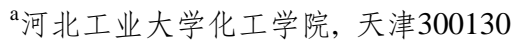 \\ b 中国科学院过程工程研究所生化工程国家重点实验室, 北京100190
}

\begin{abstract}
摘要: 将脂质体囊泡与仿生硅化技术相结合, 模拟细胞纳微环境, 实现以脂质体为模板仿生制备氧化硅固定葡萄糖氧化酶(GOx), 建立性能稳定的固定化酶. 扫描电镜分析显示, 固定化GOx为球形纳米粒子, 粒径分布在 $200 \mathrm{~nm}$ 左右, 在优化反应条件下GOx回 收率达到71.8\%. 由于载体的空间限制作用及其提供的较稳定微环境, 固定化GOx表现出良好的热稳定性和pH稳定性, 其对变性 剂耐受性和操作稳定性等也得到明显提高.
\end{abstract}

关键词: 仿生硅化; 脂质体; 葡萄糖氧化酶; 固定化酶

收稿日期: 2012-10-30. 接受日期: 2012-12-24. 出版日期: 2013-04-20.

*通讯联系人. 电话/传真: (022)60204945; 电子信箱: yanjunjiang@hebut.edu.cn

\#通讯联系人. 电话/传真: (022)60204293; 电子信箱: jgao@hebut.edu.cn

基金来源：国家自然科学基金(21006020, 21276060, 21276062); 河北省自然科学基金(B2010000035, B2011202095); 河北省高等 学校科学技术研究重点项目(ZD2010118); 河北省应用基础研究计划重点基础研究项目(11965150D); 生化工程国家重点实验室 开放课题.

本文的英文电子版由Elsevier出版社在ScienceDirect上出版(http://www.sciencedirect.com/science/journal/18722067).

\section{1. 前言}

硅溶胶-凝胶 ${ }^{[1,2]}$ 材料在酶固定化研究领域具有重要 的研究意义. Brennan课题组 ${ }^{[3,4]}$ 已经将其成功应用于酶 固定领域. 为进一步提高固定化酶活性, 人们常采用不 同措施对溶胶-凝胶固定化酶进行优化 ${ }^{[58]}$ : (1)利用有机 改性硅酸盐; (2)加入多糖作为添加剂保护酶分子; (3) 利用硅酸钠作为前驱体. 事实证明, 氧化硅固定化酶能 够有效削弱反应环境中各种离子、基团对酶结构及活性 位点的影响, 可提高酶稳定性. 虽然溶胶-凝胶可形成一 个可控的反应环境, 但在此过程中未能提供一个像模

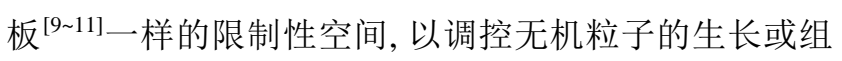
装. 所以, 此过程中较难得到形貌可控、分散均匀的微载 体, 这在一定程度上限制了溶胶-凝胶法广泛应用与发 展 ${ }^{[12]}$. 另外, 相对于传统溶胶-凝胶技术中需用强酸、强 碱等 $\mathrm{pH}$ 条件, 仿生硅化 ${ }^{[13,14]}$ 过程模拟生物体内硅化过 程, 条件温和且结构可控, 受到越来越多关注. Morse课 题组 ${ }^{[15]}$ 以半胱胺为诱导剂, 模拟硅蛋白 ${ }^{[16]}$ 催化作用, 进 行正硅酸甲酯(TMOS)水解、聚合以实现对茧火虫苂光 素酶的固定. 针对溶胶-凝胶法存在的问题, Galarneau

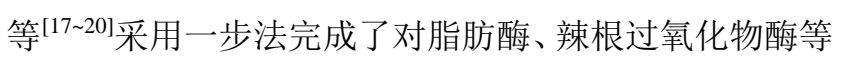
的固定. 该法首先将卵磷脂与诱导剂十二胺同时加入分 散相乙醇中, 然后慢慢滴加酶溶液, 使其形成含酶的脂 质体微囊模板, 同时完成十二胺诱导的仿生硅化过程.
此方法避免了酶分子与硅的直接接触, 在温和的条件下 改善了载体形貌, 具有一定的意义. 但仍需进一步改进, 以实现可控载体的温和制备.

本文基于仿生硅化的理念, 首先将酶包裹于脂质体 中, 然后以脂质体为模板, 在诱导剂聚二甲基二烯丙基 铵(PDADMA)作用下, 硅前驱体在脂质体表面脱水形成 氧化硅壳层, 完全避免了酶与硅前驱体的直接接触, 进 而实现了固定化酶保持较高活性的目的. 同时, 以脂质 体微囊为模板可实现形貌可控的氧化硅微粒的制备; 最 后利用低浓度表面活性剂Trtion X-100去除模板脂质体.

在此包埋过程中, 首先实现了酶与复杂包埋环境的 分离, 避免酶分子与硅烷醇间形成共价键, 保护酶活性 位点, 脂质体模板的存在实现了对载体形貌的控制, 同 时去除模板优化了传质.

\section{2. 实验部分}

\section{1. 包覆葡萄糖氧化酶脂质体模板的制备}

将卵磷脂(BR, 生化试剂, 北京奥博星生物技术有限 公司)与胆固醇(BR, 生化试剂, 北京奥博星生物技术有 限公司) 以质量比 $4: 1$ 溶于氯仿 $(\geqslant 99.5 \%$, 天津市江天化 工技术有限公司)中, 于 $4{ }^{\circ} \mathrm{C}$ 冷藏保存待用. 取一定量上 述溶液于 $100 \mathrm{ml}$ 圆底烧瓶中, 利用真空旋转蒸发仪蒸去 溶剂氯仿, 直至在烧瓶内壁形成均匀的透明薄膜. 加入 一定量酶(Glucose oxidase, G0243-50 KU, 生工生物工 
程(上海)有限公司)溶液(GOx, $100 \mathrm{mmol} / \mathrm{L} \mathrm{PBS}, \mathrm{pH}$ 7), 利用超声形成均匀的脂质体乳浊液, 控制超声时间可实 现对模板形貌和酶活保持的优化.

\section{2. 以脂质体为模板诱导形成二氧化硅壳层}

经过超声后形成粒径均匀的脂质体溶液, 在激烈振 荡条件下依次滴加PDADMA(20\%, Sigma-Aldrich)溶液 ( $2 \mathrm{mg} / \mathrm{ml}, 100 \mathrm{mmol} / \mathrm{L} \mathrm{PBS}, \mathrm{pH}$ 7)、TMOS( $\geqslant 99.95 \%$, 天 津市化学试剂一厂), 水解液 (8.188 mg/ml, $\mathrm{pH}$ 7). 硅化 $60 \mathrm{~min}$ 后离心洗涤5次.

\section{3. 去除脂质体模板}

将已除去游离酶和杂质的固定化酶在一定浓度的 Triton X-100 溶液中浸泡 $60 \mathrm{~min}$, 离心洗涤 2 次, 得到除 去模板的固定化酶. 固定化过程如图式1所示.

\section{4. 固定化GOx的包埋率的测定}

采用考马斯亮蓝G250染色法测定上清中未被固定 蛋白含量. 包埋率 $E(\%)=100 \% \times\left(1-P_{\mathrm{s}} / P_{\mathrm{t}}\right)$, 式中 $P_{\mathrm{s}}$ 和 $P_{\mathrm{t}}$ 分别为未被固定游离蛋白含量 $(\mathrm{mg})$ 和固定时所用总蛋 白量(mg).

\section{5. 固定化GOx活性分析方法}

构建一双酶体系以实现对固定化GOx活性的分析. GOx催化底物葡萄糖产生原位 $\mathrm{H}_{2} \mathrm{O}_{2}$, 辣根过氧化物酶催 化原位 $\mathrm{H}_{2} \mathrm{O}_{2}$ 与苯酚反应生成有色基团, 根据此反应体系 在500 nm下吸光值表征GOx催化速率.

在 $40{ }^{\circ} \mathrm{C}, \mathrm{pH}$ 6条件下, 1 min催化产生 $1 \mu \mathrm{mol} \mathrm{H}_{2} \mathrm{O}_{2}$ 所 需的酶量定义为一个活力单位 $(U)$.

(1) $\mathrm{H}_{2} \mathrm{O}_{2}$ 标准曲线的测定.

(2) 底物溶液的配置. A液: $0.35 \mathrm{mg}$ 辣根过氧化物 酶(HRP), $0.35 \mathrm{mg}$ 4-氨基安替吡啉(4-AAP)和 $1 \mathrm{ml} \mathrm{3 \%}$ 苯 酚溶于 $20 \mathrm{ml}$ PBS (0.1 mmol/ml) 中; B液: $13 \%$ 葡萄糖溶 液.

(3) 操作步骤: 在 $1 \mathrm{~cm}$ 比色血中, 各加 $1.5 \mathrm{ml} \mathrm{A}$ 液和 $\mathrm{B}$ 液, 充分混合, 作为参比液; 在 $10 \mathrm{~cm}$ 离心管取一定量 待测样品, 加入 $1.5 \mathrm{ml} \mathrm{A}$ 液混匀, 再加入 $1.5 \mathrm{ml} \mathrm{B}$ 液的同 时开始计时, 磁力搅拌反应 $1 \mathrm{~min}$, 迅速过滤分离出固定 化GOx以终止反应, 测上清液在 $500 \mathrm{~nm}$ 下吸光值.

$$
\text { 酶活力 } U=\frac{t \times m}{V\left(C_{\mathrm{o}}-C_{\mathrm{e}}\right) \times 10^{3}}
$$

式中, $t$ 为反应时间 (min), $m$ 为固定化酶或游离酶质量 $(\mathrm{g})$, $V$ 为反应体系体积 $(\mathrm{ml}), C_{\mathrm{o}}$ 和 $C_{\mathrm{e}}$ 分别为 $\mathrm{H}_{2} \mathrm{O}_{2}$ 初始和剩余 浓度(mol/L).

$$
\text { 酶活回收率 } R e=100 \% \times A_{\mathrm{i}} / A_{\mathrm{f}}, A_{\mathrm{f}}=A_{\mathrm{f}} \times E
$$

式中, $A_{\mathrm{i}}$ 和 $A_{\mathrm{f}}$ 分别为固定化酶的实际酶活力 $(U)$ 和理论酶 活力 $(U), A_{\mathrm{f}}$ 为固定时使用的游离酶总活力 $(U), E$ 为包埋
率(\%).

\section{3. 结果与讨论}

首先对诱导剂PDADMA(2 mg/ml, $100 \mathrm{mmol} / \mathrm{L}$ PBS, $\mathrm{pH}$ 6)、前驱体TMOS水解液 $(8.188 \mathrm{mg} / \mathrm{ml})$ 的加入量以及 去膜表面活性剂Triton X-100的加入浓度和超声时间对 GOx固定效果的影响进行了相应的优化研究. 结果表 明, 在脂质体浓度为 $18.75 \mathrm{mg} / \mathrm{ml}$ (脂质体质量以干重计), PDADMA和TMOS用量分别为 0.02 和 $0.262 \mathrm{mg} / \mathrm{mg}$ 时, 酶 活回收率最大; 在Triton X-100浓度(质量分数)为 $1.5 \%$ 时模板去除最彻底, 且该浓度下的表面活性剂对酶分子 的影响最小; 超声促进脂质体的破碎再重组过程, 利于 得到较小粒径分布的脂质体, 提高载体的比表面积, 但 过度超声会对酶分子构象造成破坏. 综合考虑, 将超声 时间控制在120 min.

\section{1. 脂质体大小控制及其 $\mathrm{SiO}_{2}$ 壳层形成情况}

本课题采用薄膜分散法制备脂质体, 利用超声促进 脂质体破碎再重组原理, 通过调节超声时间以控制脂质 体大小. 实验中, 对不同超声时间的脂质体和以相应脂 质体为模板所制备固定化GOx作DLS分析. 如图1所示, 在120 min内, 随超声时间延长, 脂质体分散度增强, 粒径 减小; $120 \mathrm{~min}$ 后随超声时间延长, 脂质体粒径已趋于 稳定, 保持在 $50 \mathrm{~nm}$ 左右.

前驱体水解液以脂质体为模板, 在其表面脱水形成 $\mathrm{SiO}_{2}$ 壳层, 由图1可知, 较小粒径脂质体利于得到分散均 匀、粒径较小的二氧化硅微囊. 实验中选取超声 $120 \mathrm{~min}$ 的脂质体为模板, 此时固定化GOx大小为 $200 \mathrm{~nm}$ 左右; 无模板时, 即在酶溶液中直接加入诱导剂和前驱体, $\mathrm{SiO}_{2}$ 粒径分布在 $900 \mathrm{~nm}$ 左右. 由图1对比发现, 模板的存 在有效改善了二氧化硅微囊的粒径分散.

\section{2. 不同壳层粒径大小对固定化酶的影响}

图2考察了以不同超声时间脂质体为模板所制备固 定化GOx的活性差异. 由图可见, 微囊粒径受控于脂质 体超声时间: $120 \mathrm{~min}$ 内, 随超声时间延长, 粒径减小, 固 定化GOx的活性升高; $120 \mathrm{~min}$ 后, 随超声时间延长, 粒 径已趋于稳定, 超声对酶分子的破坏作用明显, 固定化 GOx的活性迅速下降. 综上所述, 以超声时间 $120 \mathrm{~min}$ 的 脂质体为模板, 所得粒径 $200 \mathrm{~nm}$ 左右的固定化GOx的活 性最高.

\section{3. 二氧化硅微囊的外形}

用扫描电子显微镜(SEM, S-4800, JEOL公司)观察 二氧化硅微囊形貌. 如图3所示, 微囊粒径分布较均匀, 约在 $200 \mathrm{~nm}$ 左右. 脂质体模板的存在, 使氧化硅载体形 
貌规整, 粒径分布均匀, 同时较小粒径固定化酶表现出 较高催化性能.

\section{4. 固定化GOx的热稳定性}

以游离GOx和固定化GOx的相对酶活来考察 $\mathrm{GOx}$ 经固定化前后的热稳定性, 将游离和固定化GOx分别在 不同温度的缓冲液中浸泡 $120 \mathrm{~min}$. 如图 4 所示, $70{ }^{\circ} \mathrm{C}$ 时 游离GOx完全失活, 而固定化GOx保留了约 $40 \%$ 的相对 酶活; 在 $25,30,35,40,45$ 和 $50{ }^{\circ} \mathrm{C}$ 时, 固定化 GOx仍维持 $80 \%$ 以上活性, 与文献[21]结果相似. 这说明将GOx包埋 在氧化硅中可有效提高其热稳定性.

氧化硅载体为GOx提供稳定的微环境, 同时将GOx 紧紧束缚于狭小的空间中, 既有效降低了GOx分子表面 水化层的解离速度, 又有效的限制了酶分子的构象变化, 使包埋后的GOx表现出较高的热稳定性 ${ }^{[22]}$.

\section{5. 固定化GOx的pH稳定性}

将游离和固定化 GOx 分别在不同 $\mathrm{pH}$ 缓冲液中浸泡 $120 \mathrm{~min}$, 考察其在不同 $\mathrm{pH}$ 梯度下稳定性, 结果示于图5. 可以看出, 固定化GOx可在较宽酸碱范围内保持较高活 性. 在 $\mathrm{pH}<4.5$ 的环境下游离酶活性急剧下降, 而固定化 酶活力在 $\mathrm{pH}$ 3.5时仍能保持 $78.3 \%$; 在 $\mathrm{pH}$ 8环境下固定 化GOx活性保持在 $82.6 \%$, 高于游离GOx的 $55.2 \%$, 与文 献[21]结果相似.

在极端 $\mathrm{pH}$ 环境中, 溶液中较高浓度的 $\mathrm{OH}^{-}$和 $\mathrm{H}_{3} \mathrm{O}^{+}$会 频繁进攻酶分子, 致使酶分子表面静电荷受到严重的影 响, 降低了酶分子间的静电相互作用, 进而使得酶分子 表面的水化层受到破坏, 造成酶的构象转变. 氧化硅载 体的存在尽量降低酶分子所在微环境中的 $\mathrm{OH}^{-}$和 $\mathrm{H}_{3} \mathrm{O}^{+}$ 浓度, 从某种程度上降低了它们对酶分子的进攻频率, 使固定化GOx表现出较高的pH稳定性 ${ }^{[22]}$.

\section{6. 固定化GOx对变性剂的抵抗性}

一般酶的反应环境较复杂, 而且反应过程中会同时 产生大量的中间产物对酶产生抑制作用. 为研究固定化 酶对变性剂的耐受能力, 分别对其在一定浓度盐酸胍、

尿素、 $\mathrm{H}_{2} \mathrm{O}_{2}$ 中的酶活保持能力与同等条件的游离酶进行 比较.

盐酸胍和尿素是研究蛋白质变性时最常用的变性 剂, 它们对蛋白质分子构象的破坏比极端 $\mathrm{pH}$ 、温度和其 他变性剂更高效彻底. 然而在中性环境中, 虽然较低浓 度的盐酸胍和尿素已经使GOx活性出现明显下降, 但酶 分子构象并未发生任何改变 ${ }^{[22]}$, 即使在较高浓度的盐酸 胍和尿素中GOx分子构象仍具有较高的保持能力.

盐酸胍作为一种双功能物质, 其附带的胍盐具有很
强的变性作用, 所以盐酸胍使酶分子失活有两方面的作 用: 酶分子变性和离子效应. 总之, 盐酸胍是一种比尿 素作用更强的变性剂. 据报道, 当盐酸胍浓度在 1.8 $\mathrm{mol} / \mathrm{L}$ 以下时, 破坏的只是酶分子表面的离子层; 当浓度 升至2 4 mol/L时, 酶分子的二级结构被破坏 ${ }^{[22]}$. 在实验 过程中, 将游离和固定化GOx同时浸泡在 $2 \mathrm{~mol} / \mathrm{L}$ 盐酸胍 中, 测定其在此条件下 $120 \mathrm{~min}$ 内的酶活保持性(图6(a)). 结果发现, 由于载体为酶分子提供了较稳定的微环境, 以及空间限制等作用, 固定化酶的活性明显高于游离酶.

对于低浓度尿素而言, 仅酶活性位点的微环境被改 变; 据文献所述, 在中性变性剂环境中失活的GOx在去 除尿素后可恢复到原有酶活的 $90 \%$. 当尿素浓度为 2 $\mathrm{mol} / \mathrm{L}$ 时, 酶活性已经明显下降; 至 $8 \mathrm{~mol} / \mathrm{L}$ 时才可使酶 分子发生不可逆的变性. 实验中, 将游离和固定化 GOx 同时浸泡在 $8 \mathrm{~mol} / \mathrm{L}$ 尿素中, 测定其 $120 \mathrm{~min}$ 内酶活保持 性(图6(b)). 结果发现, 由于载体为酶分子提供较稳定的 微环境, 以及空间限制等作用, 固定化GOx的活性明显 高于游离GOx ${ }^{[22]}$.

$\mathrm{H}_{2} \mathrm{O}_{2}$ 作为反应的必要产物, 当其浓度过高时会包覆 在酶活性位点周围使酶失活, 不利于酶保持较高的操作 稳定性. 这也是GOx使用寿命缩短的主要原因 ${ }^{[23]}$. 为研 究固定化酶在 $\mathrm{H}_{2} \mathrm{O}_{2}$ 中的稳定性, 将固定化 GOx 和游离 GOx浸泡在 $10 \mathrm{mmol} / \mathrm{L} \mathrm{H}_{2} \mathrm{O}_{2}$ 中, 测定其 $120 \mathrm{~min}$ 内的酶活 保持性. 由图6(c) 可知, 固定化 $\mathrm{GOx}$ 对 $\mathrm{H}_{2} \mathrm{O}_{2}$ 的耐受能力 远远高于游离GOx. 对于固定化GOx, 其产物扩散易受 到微环境约束作用, 造成 $\mathrm{H}_{2} \mathrm{O}_{2}$ 在微环境中富集, 但同时 载体的空间限制作用又有效控制了酶活性位点的解离. 综上所述, $\mathrm{H}_{2} \mathrm{O}_{2}$ 富集对酶的抑制作用弱于载体空间限制 作用, 所以固定化GOx表现出更高的 $\mathrm{H}_{2} \mathrm{O}_{2}$ 耐受性.

\section{7. 固定化GOx的储藏稳定性}

分别测定于 $\mathrm{pH} 6$ 的缓冲液中 $4{ }^{\circ} \mathrm{C}$ 下储藏 $30 \mathrm{~d}$ 后的游 离和固定化GOx的剩余酶活, 结果如图7所示. 固定化 GOx的酶活保持最初的 $86 \%$, 而游离GOx已降至 $67 \%$. 由 此可见, 固定化后酶的储藏稳定性升高.

通常在酶的存放过程中, 酶活的丧失主要是由于微 生物的降解. 而对于固定化GOx来说, 氧化硅载体的微 孔结构能有效防止微生物进入孔内降解GOx, 从而使其 活性得到保持 ${ }^{[24]}$.

\section{8. 固定化GOx的操作稳定性}

将固定化GOx与底物葡萄糖连续反应 7 次, 研究其 操作稳定性, 发现其催化特性仍能保持 $74 \%$. 无机材料 二氧化硅的存在实现了酶反应后从反应体系的回收, 能 
够有效节约酶在工业应用的成本.

如图8所示, 随反应次数增加, 固定化GOx活性下降, 可能是由于反应产物堵塞固定化酶载体的空隙, 影响传 质速率, 以及在固定化GOx内部自由基的堆积, 导致部 分GOx的失活 ${ }^{[22]}$.

\section{4. 结论}

将脂质体囊泡技术和仿生硅化有效结合用于固定 化酶, 有效避免了包埋过程中前驱体对酶分子活性位点 及空间构象的影响. 脂质体的存在不仅可以控制二氧化 硅载体的形貌、粒径, 而且在包埋过程中对酶分子进行
包覆保护, 避免酶分子暴露在含有大量醇羟基、氨基等 易对酶结构造成破坏的包埋环境中. 仿生硅化可在较温 和的条件下进行, 避免了传统方法制备纳米粒子时极端 $\mathrm{pH}$ 等苛刻条件对酶分子的破坏. 利用表面活性剂去除 模板脂质体, 降低其对产物、底物等扩散作用的制约. 固 定化GOx较游离GOx表现出更高的稳定性, 以及较高的 热稳定性、操作稳定性和对变性剂的耐受能力. 脂质体 为模板仿生硅化固定GOx进一步促进了仿生思想向固 定化酶领域的延伸, 降低游离酶向固定化酶转变时造成 的损失, 为酶的固定化技术在工业中的应用奠定了理论 基础. 